\title{
STRATEGIC DECISION-MAKING LOGICS, ENTREPRENEURIAL CAPABILITY AND OPPORTUNITY EXPLOITATION IN HIGH-TECH NEW VENTURES
}

\author{
Runping GUO* \\ Department of Technological Economics and Management, School of Management, \\ Jilin University, Changchun, China
}

Received 28 November 2017; accepted 02 July 2018

\begin{abstract}
This paper aims at exploring the influences of effectuation and causation on opportunity exploitation in high-tech new ventures and the mediating role of entrepreneurial capability by integrating effectuation theory and a perspective of entrepreneurial capability. The data was collected from entrepreneurs and top executives in high-tech new ventures through an interview survey instrument implemented in China. Factor analysis and multivariate linear regressions were run to test the hypotheses. The Baron and Kenny (1986) mediation model assessment procedure was used to analyze the data. The empirical analysis results of 176 Chinese high-tech new ventures indicate that both effectuation and causation have positive effects on opportunity exploitation and that entrepreneurial capability plays a fully mediating role in the relationship between strategic decision logic and opportunity exploitation. It is also found that in the context of China's transition economy, the interaction effect between effectuation and causation on opportunity exploitation and entrepreneurial capability is insignificant. The research furthers the development of effectuation theory and enriches current literature on entrepreneurial capability by linking strategic decision-making logics to entrepreneurial capability and opportunity exploitation systematically. Moreover, the research has significant managerial implications for high-tech entrepreneurial practices, particularly in transition economies.
\end{abstract}

Keywords: strategic decision-making logic, opportunity exploitation, entrepreneurial capability, high-tech new ventures, entrepreneurship, transition economies.

JEL Classification: L26, M13, O32.

\section{Introduction}

Effectuation theory, an emerging strategic entrepreneurship theory, has suggested that effectuation and causation are two different strategic decision-making logics both of which are crucial to new ventures' survival and growth under high uncertainty (Reymen, Andries, Berends, Mauer, Stephan, \& Burg, 2016; Sarasvathy, 2001; Guo, Cai, \& Zhang, 2016). Scholars

*Corresponding author. E-mail: grp0925@163.com

This is an Open Access article distributed under the terms of the Creative Commons Attribution License (http://creativecommons. org/licenses/by/4.0/), which permits unrestricted use, distribution, and reproduction in any medium, provided the original author and source are credited. 
widely consider that causation represents a planned strategy which is goals-driven and characterized by avoiding unexpected factors and maximizing the expected return based on prediction logic (Perry, Chandler, \& Markova, 2012). On the other hand, effectuation, consistent with an emergent strategy, focuses on utilizing the resources at hand, relying on control logic to take advantage of contingency and evaluate affordable loss (Wiltbank, Dew, Read, \& Sarasvathy, 2006; Cai, Guo, Fei, \& Liu, 2017). Existing research has mainly focused on the impacts of effectuation and causation on entrepreneurial outputs and behaviors such as new venture performance (Read, Song, \& Smit, 2009; Smolka, Verheul, Burmeister-Lamp, \& Heugens, 2016), international entrepreneurship (Sarasvathy, Kumar, York, \& Bhagavatula, 2014) and opportunity recognition (Maine, Soh, \& Santos, 2015). Markin, Swab and Marshall (2016) conclude that entrepreneurship research as a distinct and legitimate research area is concerned with the study of the processes of discovery, evaluation, and exploitation of opportunities. While opportunity exploitation is widely considered as the key process of entrepreneurship, a key component of strategic decision-making in new ventures (Ardichvili, Cardozo, \& Ray, 2003; Foss, Lyngsie, \& Zahra, 2013; Uygur, 2016), few scholars have linked effectuation and causation to opportunity exploitation systematically to provide deeper insights into the relationship among them.

Scholars have proposed that entrepreneurial capability, which refers to the capability of sensing, selecting, shaping and synchronizing opportunities, is a key determinant to opportunity exploitation (Zahra, Abdelgawad, \& Tang, 2011; Abdelgawad, Zahra, Svejenova, \& Sapienza, 2013). Olugbola (2017) proposes that entrepreneurial capability is required to ensure perfection of administration in creation of new ventures. In an effort to cope with the high uncertainty caused by both the market and technology, high-tech new ventures must effectively apply strategic decision-making logics to maximize their internal and external resources, thereby developing their entrepreneurial capability (Reymen et al., 2016; Teece, 2012). Little research on entrepreneurial capability has systematically examined its relationship to strategic decision-making logics and opportunity exploitation. Based upon effectuation theory, firm resources such as technology resources, human resources and knowledge resources are the key element of strategic decision-making logics (Sarasvathy \& Dew, 2005). Effectuation allows high-tech new ventures to explore new ways of resource combination flexibly for entrepreneurial capability development by trial-error learning (Guo et al., 2016). Causation enables high-tech new ventures to optimize their resource portfolio to build entrepreneurial capability based on pre-defined goals (Chandler, Detienne, Mckelvie, \& Mumford, 2011). When taken together, this perspective of entrepreneurial capability provides a helpful theoretical lens through which to explain how strategic decision-making logics contribute to opportunity exploitation in high-tech new ventures.

Huarng and Ribeiro-Soriano (2014) state that entrepreneurship contributes to the quality and future hopes of a sector, economy or even a country through summarizing the best papers of the Global Innovation and Knowledge Academy (GIKA) conference. According to China Report of Global Entrepreneurship Monitor (GEM) in 2015/2016, about $64.29 \%$ of entrepreneurial activity is driven by opportunity. Given the emerging market and dynamic institutional changes in China's transition economy (Ahlstrom \& Bruton, 2010; Cai et al., 2017), high-tech new ventures are particularly required to use strategic decision-making 
logics for building entrepreneurial capability and thereby exploit the available opportunity successfully (Reymen et al., 2016). Because of the unique conditions, China, the largest transition economy provides us an ideal research context.

This research aims to explore the influence mechanism of strategic decision-making logics on opportunity exploitation in high-tech new ventures using data from China by integrating effectuation theory and the perspective provided by entrepreneurial capability. This paper is organized in four sections. Firstly, the theoretical background and the hypotheses of this research are proposed in Section 1. Then, the methodology employed is illustrated in Section 2 and the analysis results are presented in Section 3. Finally, the key findings and research implications are discussed followed by a discussion of research limitations and future directions for continuing research.

\section{Theoretical framework and hypotheses development}

Effectuation theory proposes that entrepreneurial firms when facing high uncertainty will use not only causation logic, which refers to selecting the means to realize the given goals, but also effectuation logic to choose goals created by the given means (Sarasvathy, 2001). Similar to rational strategic decision-making tools like SWOT and TOWS for environment analysis (Aslan, Çınar, \& Kumpikaite, 2012), causation emphasizes competitive analysis and intensive market research to predict and analyze external competitive environment for formulating strategic plan (Perry et al., 2012). Moreover, causation is focused on exploiting existing resources and capabilities efficiently for maximizing the expected return based on pre-defined goals (Sarasvathy, 2001). Different from traditional strategic decision-making tools, effectuation provides another approach for strategy formulation based on the logic of control (Reymen et al., 2016; Wiltbank et al., 2006). Effectuation allows new ventures to create strategic goals through entrepreneurial actions and human imagination under uncertainty (Chandler et al., 2011; Sarasvathy, 2001). Moreover, new ventures using effectuation will try to co-create the future through interacting with stakeholders and iterative learning instead of formulating competitive strategy using strategic decision-making tools like SWOT and TOWS (Maine et al., 2015). The debates on the relationship between causation and effectuation still exist among scholars, primarily due to the lack of empirical evidence. Some scholars argue that effectuation and causation can be combined at the same time to pursue superior organizational performance (Smolka et al., 2016), some consider them to be orthogonal and, thus, independent of one another (Perry et al., 2012). Still, others argue that causation and effectuation are completely opposites of each other (Brettel, Mauer, Engelen, \& Küpper, 2012). In this paper, effectuation and causation are not mutually exclusive but complementary so that they can be used together to promote entrepreneurial activities.

Opportunity exploitation is widely considered as the fundamental question in the field of entrepreneurship research (Shane \& Venkataraman, 2000; Foss et al., 2013). Scholars have argued that new ventures need effectuation and causation as strategic decision-making tools to allocate resources for opportunity exploitation (Reymen et al., 2016; Guo et al., 2016). Effectuation and causation, are particularly important for high-tech new ventures which must 
cope with the higher uncertainty created by rapidly changing of markets and technologies to successfully exploit new opportunities.

In view of existing literature, effectuation theory can be linked to a perspective of entrepreneurial capabilities theoretically (Sarasvathy et al., 2014). Scholars have proposed that effectuation and causation as strategic decision-making logics help new ventures acquire, coordinate and leverage resources, and that the dynamic resource allocation and reconstruction lead to the development of entrepreneurial capability (Zahra et al., 2011; Reymen et al., 2016). For high-tech new ventures facing greater challenges of survival, effective resource combination is particularly critical to enhance entrepreneurial capability (Mckelvie \& Davidsson, 2009). Thus, effectuation and causation are the determinants of entrepreneurial capability in high-tech new ventures.

Firms' entrepreneurial capability consists of four distinct but interrelated dimensions including sensing, selecting, shaping and synchronizing to pursue opportunities (Zahra et al., 2011; Abdelgawad et al., 2013). Based on current studies, sensing capability means seeing or envisioning opportunities within as well as beyond the confines of an industry; shaping capability refers to integrating available resources to create and realize opportunity; selecting capability denotes the ability of entrepreneurs and manager to judge and evaluate potential opportunities; and synchronizing capability refers to co-aligning opportunities through orchestrating internal and external resources and capabilities (Zahra et al., 2011; Abdelgawad et al., 2013; Olugbola, 2017). The interaction among these dimensions contributes to opportunity exploitation. Overall, entrepreneurial capability is the key mediator in the relationship between strategic decision-making logics and opportunity exploitation in high-tech new ventures. Drawing on effectuation theory and a perspective of entrepreneurial capability, the research model is built (Figure 1) exploring the influences of strategic decision-making logics on opportunity exploitation, and the mediating role of entrepreneurial capability in the relationship described.

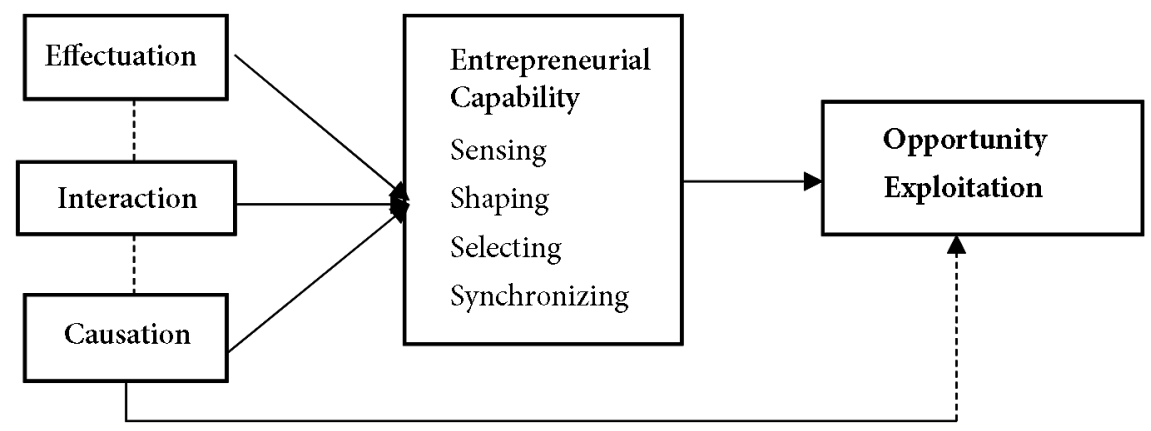

Figure 1. Research model

\subsection{Strategic decision-making logics and opportunity exploitation}

Given that entrepreneurial opportunity exploitation involves resource investment and allocation under uncertainty, effectuation and causation each provides a different path for resource acquisition and coordination for high-tech new ventures to exploit opportunities. 
According to effectuation theory, effectuation emphasizes strategic experiments, affordable loss principle, maintaining flexibility and pre-commitments to control unpredictable future. This encourages high-tech new ventures to creatively combine resources to exploit potential opportunities (Sarasvathy, 2001; Perry et al., 2012). Specifically, high-tech new ventures are able to focus on viable opportunities and explore different ways of resource combination through series of strategic experiments relying on trial-and-error learning to optimize outcomes (Deligianni, Voudouris, \& Lioukas, 2015; Guo et al., 2016). Given that high-tech new ventures are more vulnerable to entrepreneurial failure due to liability of newness compounded by technology uncertainty, the affordable loss principle is particularly important for investing resources step-by-step to exploit feasible opportunities (Dew, Sarasathy, Read, \& Wiltbank, 2010). In high-tech new ventures, maintaining flexibility encourages improvisation and creative resource combination allowing them to exploit emerging opportunities (Vera \& Crossan, 2005; Baker \& Nelson, 2005). Moreover, pre-commitments are incredibly important for high-tech new ventures to acquire resources before providing products or services and establish strategic partnership with external stakeholders who introduce a variety of complementary resources and knowledge to them, thus facilitating creative opportunity exploitation (Read et al., 2009; Alvarez \& Barney, 2007). To sum up, hypothesis 1a is proposed:

H1a: Effectuation has a positive effect on opportunity exploitation in high-tech new ventures.

Unlike effectuation, causation focuses on exploiting existing resources and capabilities to accomplish pre-defined goals, maximizing expected return, and to predict future risk through business plan and competitive analysis, which enables high-tech new ventures to quickly exploit current opportunities (Reymen et al., 2016; Chandler et al., 2011). Specifically, pre-defined goals enable employees to share clear strategic visions within high-tech new ventures and take actions that are consistent with shared goals to promptly exploit current opportunities. Moreover, business plan and competitive analysis help high-tech new ventures systematically search and analyze information, thus formulating entrepreneurial strategy to quickly convert the opportunities recognized into new product or services (Parida, George, Lahti, \& Wincent, 2016). High-tech new ventures that use the principle of maximizing the expected return, are also able to deliberately optimize their current resource portfolio to strategically exploit the value of opportunities available in the market (Fisher, 2012). Due to the lack of an established reputation, high-tech new ventures often face greater obstacles to acquiring external resources (Stinchcombe, 1965). Causation allows these ventures to efficiently exploit existing resources and capabilities to capture the timing of opportunity exploitation. Accordingly, the arguments above are summarized as hypothesis $1 \mathrm{~b}$ :

H1b: Causation has positive effect on opportunity exploitation in high-tech new ventures. Effectuation and causation can be combined to facilitate opportunity exploitation in hightech new ventures (Reymen et al., 2016). On the one hand, analysis and planning components inherent in causation provide high-tech new ventures using effectuation to exploit creative opportunities with critical information and legitimacy necessary to acquire resources for experimentation. And pre-defined goals afforded by causation logic allow these ventures employing effectuation to quickly identify and exploit viable opportunities in the strategic experiments with clear strategic direction. On the other hand, given that effectuation focuses 
on experimentation and flexibility, it allows high-tech new ventures using causation the option to use a variety of resource combinations and pathways to exploit current opportunities (Smolka et al., 2016). Additionally, pre-commitments and affordable loss in effectuation logic enable these ventures employing causation to maximize the expected value of opportunities while controlling risk and managing external resources to increase the success rate of opportunity exploitation (Berends, Jelinek, Reymen, \& Stultiëns, 2014). Hypothesis H1c is proposed:

H1c: The interaction between effectuation and causation has a positive effect on opportunity exploitation in high-tech new ventures.

\subsection{Strategic decision-making logics and entrepreneurial capability}

Effectuation enables high-tech new ventures to creatively combine internal and external resource for entrepreneurial capability building (Sarasvathy et al., 2014; Cai et al., 2017). Specifically, effectuation allows high-tech new ventures to embrace unpredictable future and even create completely new products or services through experimentation (Chandler et al., 2011). In such process of trial-error learning, these ventures will identify potential market needs, as well as new applications of existing resources, to develop sensing capability (Teece, 2012). The principle of affordable loss in effectuation logic enables high-tech new ventures to collect real-time information for opportunity evaluation through incremental resource investment, further developing selecting capability (Dew et al., 2010). Flexibility also encourages these ventures to integrate resources at hand creatively, building shaping capability to cope with a rapidly changing market (Baker \& Nelson, 2005). Shaping capability is also built through pre-commitments, which provide high-tech new ventures with opportunities to learn from strategic partners in different fields, incorporating novel business concepts from other fields into their own business (Powell \& Sandholtz, 2012). Pre-commitments also allow these ventures to acquire and mobilize complementary resources from their strategic partners, thereby building synchronizing capability (Abdelgawad et al., 2013). The discussions above lead to $\mathrm{H} 2 \mathrm{a}$ :

H2a: Effectuation has a positive effect on entrepreneurial capability in high-tech new ventures.

When driven by causation logic, high-tech new ventures tend to optimize current resource and capabilities to build entrepreneurial capability (Guo et al., 2016). Specifically, causation helps high-tech new ventures predict trends in business changes and discover new opportunities by searching local information and scanning the environment, thus enhancing sensing capability (Brettel et al., 2012). Causation also allows high-tech new ventures to explain the value of opportunity to external stakeholders through a well-written business plan and obtain their resource support to build shaping capability (Smolka et al., 2016). Moreover, the principle of maximizing the expected return forces these ventures to pay close attention to the profitability of opportunities, which, in turn, requires them to search sufficient information in order to evaluate potential value of opportunities to develop selecting capability (Dew et al., 2010). The principle also enables high-tech new ventures to rank different opportunities and optimize their resource combination when exploiting those opportunities with higher 
market potential (Dutta, Gwebu, \& Wang, 2015). These processes will lead to the building of synchronizing capability in high-tech new ventures. Accordingly, $\mathrm{H} 2 \mathrm{~b}$ is proposed:

H2b: Causation has a positive effect on entrepreneurial capability in high-tech new ventures.

Effectuation and causation are complementary to each other in entrepreneurial capability building. Specifically, experimentation and flexibility components inherent in effectuation provide high-tech new ventures using causation logic with real-time environmental information to accurately predict changing trends, which builds sensing capability (Chandler et al., 2011). And the affordable loss principle of effectuation provides these ventures using causation with a perspective of risk control which can be used to evaluate opportunities, thus enhancing their selecting capability (Dew et al., 2010). Moreover, pre-commitments in effectuation logic enable these ventures to build trust-based strategic partnership (Deligianni et al., 2015), which make it easier for them to gain supports from strategic partners, thus building both shaping and synchronizing capabilities. Simultaneously, causation emphasizes extensive market research and analysis (Sarasvathy \& Dew, 2005), which provide market data for effectuators to identify and address unfilled market needs through experimentation, thus developing sensing capability of a high-tech new venture. The elaborated business plan produced by causation logic is essential for effectuators to share information with external stakeholders and mobilize resources to co-create and realize opportunities in a timely and orderly manner, thus building both shaping and synchronizing capability (Smolka et al., 2016). Therefore, $\mathrm{H} 2 \mathrm{c}$ is proposed:

H2c: The interaction between effectuation and causation has a positive effect on entrepreneurial capability in high-tech new ventures.

\subsection{The mediating role of entrepreneurial capability in the relationship between strategic decision-making logics and opportunity exploitation}

Entrepreneurial capability drives high-tech new ventures to discover, create and exploit new and novel opportunities continually (Olugbola, 2017). Among dimensions of entrepreneurial capability, sensing capability and shaping capability reflect a high-tech new venture's capability to recognize opportunities, which facilitates the discovery of existing opportunities and the creation of new opportunities through entrepreneurial actions (Alvarez \& Barney, 2007; Abdelgawad et al., 2013). Selecting capability and synchronizing capability, on the other hand, represent a high-tech new venture's capability to evaluate, rank and realize these new recognized opportunities. Therefore, entrepreneurial capability improves the efficiency and effectiveness of opportunity exploitation in terms of quickly converting new opportunities with market potential into new products or services as many as possible (Zahra et al., 2011). As illustrated above, strategic decision logics are helpful for high-tech new ventures to exploit opportunities and develop entrepreneurial capabilities. Accordingly, it is expected that entrepreneurial capability is the key pathway through which strategic decision logics contribute to opportunity exploitation in high-tech new ventures. To sum up, $\mathrm{H} 3 \mathrm{a}$ and $\mathrm{H} 3 \mathrm{~b}$ are proposed:

H3a: Entrepreneurial capability has a mediating role in the relationship between effectuation and opportunity exploitation in high-tech new ventures. 
H3b: Entrepreneurial capability has a mediating role in the relationship between causation and opportunity exploitation in high-tech new ventures.

\section{Methodology}

\subsection{Sample and data collection}

The empirical data was collectd through an interview survey instrument in China. The literature considers firms to be "new ventures" if they are ten years of age or younger (Patel \& Jayaram, 2014; Milanov \& Fernhaber, 2009; Yli-Renko, Autio, \& Sapienza, 2001). Investigated companies were randomly selected from lists of local new ventures in high technology industries, as identified by the Chinese Standard Industrial Classification (SIC) code according to the National Bureau of Statistics. The data collection occurred from February, 2015 to May, 2015. To ensure the validity and generality of the data, two cities with significant differences in the levels of China Private Entrepreneurship Activity (CPEA) are chosen for the survey locations: Beijing (the capital city of China) and Changchun (the capital city of Jilin Province). Entrepreneurs and top executives from 300 high-tech new ventures in these two cities received the survey. The valid questionnaires were received from 176 respondents, for a valid respondent rate of $58.67 \%$. The respondents are mainly from the important departments in high-tech new ventures, such as R\&D (29.9\%), marketing (26.8\%) and administration/human resource management (26.2\%). Accordingly, they have a basis for understanding the meaning of the measurements and answer them correctly. The average age of responding companies is 5.42 years. Most responding companies (90.3\%) are small and medium-sized enterprises with fewer than 200 employees. The numbers of responding companies are split almost evenly between being located in Beijing (53.7\%) or Changchun (46.3\%).

\subsection{Questionnaire and measures}

The standard protocol was followed to develop measurements for the survey. The scales based on extant literature are translated from English into Chinese firstly. To ensure the accuracy of the instrument during translation, the Chinese instrument was then back translated into English by an independent third party. The process was repeated until the two versions showed little substantive difference. Then, a pilot test of the measurements with 10 entrepreneurs and top executives of high-tech new ventures was conducted until there was no longer additional feedback for revision from new respondents. The protocols above ensured the high quality of the data set obtained.

Key variables. The measurements of effectuation and causation developed by Chandler et al. (2011) were used, which have been widely used in relevant empirical research (Cai et al., 2017; Smolka et al., 2016; Deligianni et al., 2015). Entrepreneurial capability is measured as the combination of dimensions which are clearly defined by scholars (Zahra et al., 2011; Abdelgawad et al., 2013; Olugbola, 2017). Respondents were asked to score effectuation, causation and entrepreneurial capability according to their views on the items by measuring them on a scale from 1 (strongly disagree) to 5 (strongly agree). And opportunity exploitation is measured as the sum of the number of opportunities exploited based on the literature (Foss 
et al., 2013; Shane, Venkataraman, 2000). Respondents were asked to report the number of opportunities that their ventures had exploited in the previous three years.

Control variables. Company age was measured by the number of years a firm has been in existence ( $\mathrm{Su}, \mathrm{Li}$, Yang, \& Li, 2011). And company size was measured by the number of full-time employees at a company (Zahra, 2012), which were categorized into six groups (1= "less than 20 employees"; 6 = "more than 1000 employees"). Location is also a dummy variable, with a value of " 1 " assigned for Beijing and 0 otherwise.

\section{Results}

\subsection{Descriptive statistics and correlations}

The descriptive statistics of all variables are present in Table 1. The analysis results show that strategic decision logics, opportunity exploitation and entrepreneurial capability are significantly correlated with each other, indicating strong supports for the tested hypotheses.

Table 1. Descriptive statistics and correlation

\begin{tabular}{|l|c|c|c|c|c|c|c|c|c|}
\hline \multicolumn{1}{|c|}{ Variables } & Mean & S.D. & 1 & 2 & 3 & 4 & 5 & 6 & 7 \\
\hline 1. Age & 5.42 & 2.72 & 1 & & & & & & \\
\hline 2. Size & 2.05 & 1.24 & $.217^{\star}$ & 1 & & & & & \\
\hline 3. Location & 0.53 & 0.50 & 0.011 & 0.105 & 1 & & & & \\
\hline 4. Effectuation & 3.74 & 0.67 & -0.145 & 0.074 & -0.031 & 1 & & & \\
\hline $\begin{array}{l}\text { 5. Causation } \\
\text { 6. Entrepreneurial } \\
\text { Capability }\end{array}$ & 3.97 & 0.82 & -0.009 & 0.028 & -0.125 & $0.593^{* *}$ & 1 & & \\
\hline $\begin{array}{l}\text { 7. Opportunity } \\
\text { Exploitation }\end{array}$ & 16.50 & 7.70 & -0.057 & 0.118 & -0.156 & $0.318^{* *}$ & $0.388^{* *}$ & $0.330^{\star *}$ & 1 \\
\hline
\end{tabular}

Note: ${ }^{\star} \mathrm{p} \leq .05 ;{ }^{* *} \mathrm{p} \leq .01$.

\subsection{Measurement assessment}

As shown in Table 2, Table 3 and Table 4, Cronbach's alpha was used to assess the reliability of the scales, and coefficient alphas of all the variables are well above 0.7. To measure effectuation and causation in this paper, the established scales of these variables developed by Chandler et al. (2011) based on effectuation theory are used. Scholars have widely accepted that causation is a uni-dimensional construct while effectuation is a construct with four sub-dimensions of experimentation, flexibility, affordable loss and pre-commitments (Perry et al., 2012; Smolka et al., 2016; Deligianni et al., 2015). In a similar vein, entrepreneurial capability is clearly defined by scholars as a construct consisting of four distinct but interrelated dimensions of sensing, shaping, selecting and synchronizing with a strong theoretical foundation (Zahra et al., 2011; Abdelgawad et al., 2013; Olugbola, 2017). Accordingly, the content validity of the measures is supported. To further test the structural validity of the 
scales, exploratory factor analysis (EFA) through the rotation method of Varimax with Kaiser Normalization was used. The factor analysis results indicate that the scales used have strong validity given that the items are theorized to load together on the same construct actually do. Moreover, for all the variables, the accumulative variances explained of the total items for these variables are above $70 \%$. The results of the validity test are consistent with that in the existing research (Smolka et al., 2016; Deligianni et al., 2015; Zahra et al., 2011). Consequently, these results supported a reliable and valid measurement instrument. A Harmon's one factor test was also run to test potential common-method bias. In the test, the first factor explains much less than $40 \%$ of variance for all items. The results suggest that potential common-method bias is not a serious concern in this study.

Table 2 . The reliability and validity of effectuation items

\begin{tabular}{|c|c|c|c|c|c|}
\hline Effectuation & Item & Factor 1 & Factor 2 & Factor 3 & Factor 4 \\
\hline \multirow{5}{*}{$\begin{array}{l}\text { Experimentation } \\
a=0.791 \\
A V E=22.975 \%\end{array}$} & $\begin{array}{l}\text { 1. We experimented with dif- } \\
\text { ferent products and/or business } \\
\text { models. }\end{array}$ & 0.861 & 0.040 & 0.252 & 0.147 \\
\hline & \multirow{2}{*}{$\begin{array}{l}\text { 2. The product/service that we } \\
\text { now provide is substantially dif- } \\
\text { ferent than we first imagined. }\end{array}$} & 0.859 & 0.226 & 0.003 & -0.086 \\
\hline & & & & & \\
\hline & \multirow{2}{*}{$\begin{array}{l}\text { 3. We tried a number of differ- } \\
\text { ent approaches until we found a } \\
\text { business model that worked. }\end{array}$} & \multirow{2}{*}{0.599} & 0.242 & 0.518 & 0.131 \\
\hline & & & & & \\
\hline \multirow{5}{*}{$\begin{array}{l}\text { Affordable loss } \\
\mathrm{a}=0.844 \\
\text { AVE }=20.165 \%\end{array}$} & \multirow{2}{*}{$\begin{array}{l}\text { 4. We were careful not to com- } \\
\text { mit more resources than we } \\
\text { could afford to lose. }\end{array}$} & 0.048 & 0.761 & 0.268 & 0.238 \\
\hline & & & & & \\
\hline & \multirow{2}{*}{$\begin{array}{l}\text { 5. We were careful not to risk } \\
\text { more money than we were will- } \\
\text { ing to lose with our initial idea. }\end{array}$} & 0.169 & 0.884 & 0.076 & \multirow{2}{*}{0.110} \\
\hline & & & & & \\
\hline & $\begin{array}{l}\text { 6. We were careful not to risk so } \\
\text { much money that the company } \\
\text { would be in real trouble finan- } \\
\text { cially if things didn't work out. }\end{array}$ & 0.196 & 0.826 & 0.196 & 0.095 \\
\hline \multirow{5}{*}{$\begin{array}{l}\text { Flexibility } \\
\mathrm{a}=0.780 \\
\text { AVE }=16.878 \%\end{array}$} & $\begin{array}{l}\text { 7. We allowed the business } \\
\text { to evolve as opportunities } \\
\text { emerged. }\end{array}$ & 0.152 & 0.242 & 0.756 & 0.191 \\
\hline & $\begin{array}{l}\text { 8. We adapted what we were do- } \\
\text { ing to the resources we had. }\end{array}$ & 0.075 & 0.352 & 0.730 & 0.069 \\
\hline & $\begin{array}{l}\text { 9. We were flexible and took } \\
\text { advantage of opportunities as } \\
\text { they arose. }\end{array}$ & 0.283 & 0.115 & 0.782 & 0.158 \\
\hline & \multirow{2}{*}{$\begin{array}{l}\text { 10. We avoided courses of ac- } \\
\text { tion that restricted our flexibil- } \\
\text { ity and adaptability. }\end{array}$} & 0.035 & -0.002 & 0.641 & 0.235 \\
\hline & & & & & \\
\hline
\end{tabular}


End of Table 2

\begin{tabular}{|l|l|c|c|c|c|}
\hline \multicolumn{1}{|c|}{ Effectuation } & \multicolumn{1}{c|}{ Item } & Factor 1 & Factor 2 & Factor 3 & Factor 4 \\
\hline \multirow{3}{*}{$\begin{array}{l}\text { Pre-commit- } \\
\text { ments } \\
\text { a }=0.790 \\
\text { AVE }=13.821 \%\end{array}$} & $\begin{array}{l}\text { 11. We used pre-commitments } \\
\text { from customers and suppliers as } \\
\text { often as possible. }\end{array}$ & 0.000 & 0.161 & 0.398 & 0.801 \\
\cline { 2 - 6 } & $\begin{array}{l}\text { l2. We used a substantial num- } \\
\text { ber of agreements with custom- } \\
\text { ers, suppliers and other organi- } \\
\text { zations and people to reduce the } \\
\text { amount of uncertainty. }\end{array}$ & 0.090 & 0.209 & 0.151 & 0.879 \\
\cline { 2 - 6 } & & & & & \\
\hline
\end{tabular}

Table 3. The reliability and validity of causation items

\begin{tabular}{|c|c|c|c|}
\hline Item & $\begin{array}{l}\text { Factor } \\
\text { loading }\end{array}$ & Alpha & $\begin{array}{l}\text { Accumulative variance } \\
\text { explained }\end{array}$ \\
\hline $\begin{array}{l}\text { 1. We developed a strategy to best take advan- } \\
\text { tage of resources and capabilities. }\end{array}$ & 0.815 & \multirow{7}{*}{0.925} & \multirow{7}{*}{$69.268 \%$} \\
\hline 2. We designed and planned business strategies. & 0.857 & & \\
\hline $\begin{array}{l}\text { 3. We organized and implemented control pro- } \\
\text { cesses to make sure we met objectives. }\end{array}$ & 0.854 & & \\
\hline $\begin{array}{l}\text { 4. We researched and selected target markets } \\
\text { and did meaningful competitive analysis. }\end{array}$ & 0.821 & & \\
\hline $\begin{array}{l}\text { 5. We had a clear and consistent vision for } \\
\text { where we wanted to end up. }\end{array}$ & 0.861 & & \\
\hline $\begin{array}{l}\text { 6. We developed a strategy to best take advan- } \\
\text { tage of resources and capabilities. }\end{array}$ & 0.831 & & \\
\hline 7. We designed and planned business strategies. & 0.783 & & \\
\hline
\end{tabular}

Table 4. The reliability and validity of entrepreneurial capability items

\begin{tabular}{|c|c|c|c|c|c|}
\hline & Item & Factor 1 & Factor 2 & Factor 3 & Factor 4 \\
\hline \multirow{4}{*}{$\begin{array}{l}\text { Sensing } \\
a=0.813 \\
A V E=23.741 \%\end{array}$} & \multirow{4}{*}{$\begin{array}{l}\text { 1. We can alertly scan the } \\
\text { trends of new products/ser- } \\
\text { vices or technology within as } \\
\text { well as beyond the confines } \\
\text { of an industry. } \\
\text { 2. We can search the infor- } \\
\text { mation about market needs } \\
\text { or underemployed resources. } \\
\text { 3. We can imagine a new } \\
\text { business concept that does } \\
\text { not exist in the market be- } \\
\text { fore. }\end{array}$} & 0.582 & 0.554 & 0.237 & 0.237 \\
\hline & & 0.501 & 0.622 & 0.257 & 0.211 \\
\hline & & 0.840 & 0.087 & 0.288 & 0.232 \\
\hline & & & & & \\
\hline
\end{tabular}


End of Table 4

\begin{tabular}{|c|c|c|c|c|c|}
\hline & Item & Factor 1 & Factor 2 & Factor 3 & Factor 4 \\
\hline \multirow{4}{*}{$\begin{array}{l}\text { Shaping } \\
a=0.796 \\
\text { AVE }=18.034 \%\end{array}$} & \multirow{4}{*}{$\begin{array}{l}\text { 4. We can mobilize the re- } \\
\text { sources and capabilities at } \\
\text { hand internally and external- } \\
\text { ly to address new challenges. } \\
5 \text {. We can apply the underly- } \\
\text { ing logic in one products/ } \\
\text { services or markets into an- } \\
\text { other one. } \\
\text { 6. We can reason and jus- } \\
\text { tify new opportunities and } \\
\text { gain supports from external } \\
\text { stakeholders. }\end{array}$} & 0.267 & 0.507 & 0.386 & 0.445 \\
\hline & & 0.107 & 0.643 & 0.466 & 0.275 \\
\hline & & 0.068 & 0.797 & 0.142 & \\
\hline & & & & & 0.350 \\
\hline \multirow{3}{*}{$\begin{array}{l}\text { Selecting } \\
\mathrm{a}=0.836 \\
\mathrm{AVE}=21.392 \%\end{array}$} & \multirow{3}{*}{$\begin{array}{l}\text { 7. We can judge the feasibil- } \\
\text { ity of a business ideas by } \\
\text { considering resources and } \\
\text { external available resources. } \\
\text { 8. We can pursue investiga- } \\
\text { tions of presumed market } \\
\text { needs or resources to evalu- } \\
\text { ate the value of new business } \\
\text { ideas. }\end{array}$} & 0.261 & 0.217 & 0.767 & 0.350 \\
\hline & & 0.296 & 0.285 & 0.800 & \\
\hline & & & & & 0.186 \\
\hline \multirow[b]{3}{*}{$\begin{array}{l}\text { Synchronizing } \\
a=0.882 \\
A V E=15.606 \%\end{array}$} & \multirow{3}{*}{$\begin{array}{l}\text { 9. We can specify sequence, } \\
\text { pace, and timing of opportu- } \\
\text { nity execution. } \\
10 \text {. We can articulate process } \\
\text { or actions for opportunity } \\
\text { execution. } \\
11 \text {. We can articulate the } \\
\text { ranking of opportunities in } \\
\text { terms of their importance for } \\
\text { the firm. }\end{array}$} & 0.199 & 0.308 & 0.179 & 0.826 \\
\hline & & 0.102 & 0.284 & 0.222 & 0.835 \\
\hline & & 0.360 & 0.212 & 0.285 & 0.724 \\
\hline
\end{tabular}

\subsection{Hypotheses testing results}

The ordinary least square multivariate regressions were run to test the hypotheses using SPSS 20.0. The mediation hypotheses were assessed using the Baron and Kenny (1986) procedures. The variance inflation factor (VIF) values of all regression models were checked. The largest VIF value is 2.7 , well below the suggested cut off value 10. The result suggests that the regression results obtained are valid.

The analysis results of regression model are shown in Table 5. Model 1 suggests that effectuation $(\beta=0.220, \mathrm{P} \leq 0.05)$ and causation $(\beta=0.251, \mathrm{P} \leq 0.05)$ have significantly positive effect on opportunity exploitation in high-tech new ventures. Thus, H1a and H1c are supported. Model 2 indicates that the interaction effect of effectuation and causation on opportunity exploitation is insignificant $(\beta=0.035, \mathrm{P}>0.05)$. Therefore, $\mathrm{H} 1 \mathrm{c}$ is unsupported. Moreover, Model 3 shows that effectuation $(\beta=0.382, \mathrm{P} \leq 0.001)$ and causation $(\beta=0.482$, $\mathrm{P} \leq 0.001$ ) have significantly positive effects on entrepreneurial capability. It is shown that the interaction effect of effectuation and causation on entrepreneurial capability is insignificant 
in Model 4 ( $\beta=0.041, \mathrm{P}>0.05$ ). Hence, $\mathrm{H} 2 \mathrm{c}$ is unsupported. And Model 5 shows entrepreneurial capability has a positive effect on opportunity exploitation $(\beta=0.419, \mathrm{P} \leq 0.001)$. Model 6 reveals that the effects of effectuation $(\beta=0.072, P>0.05)$ and causation $(\beta=0.099$, $\mathrm{P}>0.05$ ) on opportunity exploitation (dependent variable) becomes insignificant when entrepreneurial capability (mediating variable) is entered $(\beta=0.326, \mathrm{P} \leq 0.05)$. According to the Baron and Kenny (1986) mediation model assessment procedures, the fully mediating role of entrepreneurial capability in the relationship between strategic decision-making logics and opportunity exploitation presents. Accordingly, $\mathrm{H} 3 \mathrm{a}$ and $\mathrm{H} 3 \mathrm{~b}$ are supported. $\mathrm{R}$ square of M1, M2, M5 and M6 with the independent variable of opportunity exploitation are small. The reason for this is that opportunity exploitation is an independent variable which is influenced by many other factors. Previous research have found that a great many factors such as prior knowledge, social network, personal traits and cognitive factors have impacts on opportunity exploitation (Hmieleski, Carr, \& Baron, 2015; Ardichvili et al., 2003). Besides these influence factors, the analysis results show that both strategic decision logic and entrepreneurial capability have significant positive effects on opportunity exploitation from new theoretical perspectives. Given that the sample size is small, the R square values of the regression models are reasoned.

Table 5. Multivariate linear regression of the relationship between knowledge integration method, opportunity exploitation and high-tech new venture performance

\begin{tabular}{|l|c|c|c|c|c|c|c|}
\hline \multirow{2}{*}{ Variables } & \multicolumn{3}{|c|}{ Opportunity Exploitation } & \multicolumn{2}{c|}{$\begin{array}{c}\text { Entrepreneurial } \\
\text { Capability }\end{array}$} & \multicolumn{2}{c|}{$\begin{array}{c}\text { Opportunity } \\
\text { Exploitation }\end{array}$} \\
\hline & M0 M1 & & M2 & M3 & M4 & M5 & M6 \\
\hline Age & -0.102 & -0.054 & -0.056 & -0.105 & -0.081 & -0.014 & -0.013 \\
\hline Size & -0.173 & 0.122 & 0.117 & 0.115 & 0.090 & 0.009 & 0.036 \\
\hline Location & 0.175 & -0.096 & -0.099 & -0.049 & -0.029 & -0.073 & -0.016 \\
\hline Effectuation & & $0.220^{\star}$ & $0.216^{*}$ & $0.382^{* * *}$ & $0.375^{* * *}$ & & 0.072 \\
\hline Causation & & $0.251^{\star}$ & $0.260^{\star}$ & $0.482^{* * *}$ & $0.496^{* * *}$ & & 0.099 \\
\hline $\begin{array}{l}\text { Effectuation } \\
\text { Causation }\end{array}$ & & & 0.035 & & 0.041 & & \\
\hline $\begin{array}{l}\text { Entrepreneurial } \\
\text { Capability }\end{array}$ & & & & & & $0.419^{* * *}$ & $0.326^{*}$ \\
\hline $\mathrm{R}^{2}$ & 0.050 & 0.212 & 0.213 & 0.614 & 0.615 & 0.182 & 0.213 \\
\hline Adjusted $\mathrm{R}^{2}$ & 0.023 & 0.174 & 0.168 & 0.595 & 0.592 & 0.154 & 0.165 \\
\hline $\mathrm{F}$ & 1.843 & $5.605^{* * *}$ & $4.657^{* * *}$ & $31.805^{* * *}$ & $26.399^{* * *}$ & $6.415^{* * *}$ & $4.461^{\star * *}$ \\
\hline
\end{tabular}

Note: $\mathrm{N}=176 ;{ }^{*} \mathrm{P} \leq .05 ;{ }^{* *} \mathrm{P} \leq .01 ;{ }^{* *} \mathrm{P} \leq .001$.

\section{Discussion}

The analysis results show that the hypotheses are supported except $\mathrm{H} 1 \mathrm{c}$ and $\mathrm{H} 2 \mathrm{c}$. Using the data from China, the research shows that the interaction effect between effectuation and causation on opportunity exploitation and entrepreneurial capability is insignificant. This result 
might be explained in the context of China's transition economy. As Sarasvathy (2001) states that the relationship between effectuation and causation is similar to the relationship between exploration and exploitation, where effectuation involves exploratory activities and causation dominates exploitative activities. Given that both exploration and exploitation consume the resources of firms, the balance of effectuation and causation involves the competition and allocation of scarce resources (Sarasvathy, 2001; O’Reilly \& Tushman, 2013). China is experiencing an incremental transition from a planned economy to a market economy and, therefore, the factor market and institution for technology entrepreneurship are still not wellestablished (Ahlstrom \& Bruton, 2010; Cai et al., 2017). Accordingly, Chinese high-tech new ventures must cope with stronger resource constraints on high investment for R\&D and fierce competition in the largest emerging market. Although effectuation and causation contribute to entrepreneurial capability and thus facilitate opportunity exploitation, balancing both strategic decision-making logics simultaneously requires a variety of resource investments for different strategies and organizational designs. Such a complex and resource-consuming task is a great challenge for Chinese high-tech new ventures. Instead Chinese high-tech new ventures tend to choose one strategic decision-making logic as the dominant strategy during a given period of time. Therefore, the complementary effect of effectuation and causation is insignificant in the research.

The research contributes to the extant literature from two directions. Firstly, causation and effectuation are linked to the key constructs in entrepreneurship field including opportunity exploitation and entrepreneurial capability in a transition economy. This link is necessary as proposed by Perry et al. (2012) and Smolka et al. (2016), who state that scholars need to link effectuation to more established concepts and explore its antecedent and effectiveness in order to mature effectuation theory. Accordingly, the research facilitates the development of effectuation theory. Secondly, the research sheds light on the mechanism by which strategic decision-making logics influence opportunity exploitation in high-tech new ventures from the perspective of entrepreneurial capability. In the view of current studies, there is a lack of empirical research on the antecedent and effect of entrepreneurial capability based on an integrative theoretical framework. The research enriches current literature by connecting entrepreneurial capability with effectuation theory and providing evidence for the fully-mediating role entrepreneurial capability plays in the relationship between strategic decision-making logics and opportunity exploitation.

\section{Conclusions}

Integrating effectuation theory and the perspective of entrepreneurial capability, the influence mechanism of strategic decision-making logics on opportunity exploitation in high-tech new ventures were explored and examined using data from China. Empirical analysis results indicate that both effectuation and causation have positive effects on opportunity exploitation and entrepreneurial capability in high-tech new ventures. Moreover, entrepreneurial capability plays a fully mediating role in the relationship between strategic decision-making logics and opportunity exploitation. However, the interaction effect between effectuation and causation on both opportunity exploitation and entrepreneurial capability is insignificant in 
the context of China's transition economy. The research furthers the development of effectuation theory and enriches current literature on entrepreneurial capability.

Moreover, the research findings have great implications for the opportunity exploitation of high-tech new ventures, particularly in transition economies. The results indicate that high-tech new ventures are required to apply both causation and effectuation to develop entrepreneurial capability effectively and to exploit the available opportunities successfully under high uncertainty. On the one hand, causation allows high-tech new ventures to make plans for resource optimization based on pre-defined strategic goals, which helps develop entrepreneurial capability necessary for efficiently exploiting newly discovered opportunities. On the other hand, effectuation enables high-tech new ventures to creatively combine resources through interactions with external stakeholders and develop entrepreneurial capability to co-create and exploit new opportunities. For high-tech new ventures in the context of transition economies characterized by high uncertainty and strong resource constraints, like China, new high-tech ventures must choose between effectuation and causation to determine the dominant strategic decision-making logic they will use to build the entrepreneurial capabilities of sensing, shaping, selecting, and synchronizing for opportunities exploitation.

While the research has several limitations, it also provides directions for future research. First, this research only collected cross-section data for empirical analysis. Future research would benefit from a time lag between the measurement of independent variables and dependent variables to provide stronger evidence for the causal relationship among key variables. And the use of both longitudinal case study data and panel data also helps capture the dynamic effects of dominant strategic decision-making logic evolution on opportunity exploitation and entrepreneurial capability in future research. Second, opportunity exploitation was only measured using based on the number of opportunities exploited. This research could benefit from a stronger measure of opportunity exploitation than used in this study. Other dimensions including novelty and profitability can be added to more comprehensively measure opportunity exploitation in the future studies. Third, the sample size is relatively small in this research. The data based on a larger survey sample from more cities will provide stronger empirical evidence for this research stream. Finally, the contingent factors in the relationship of key variables have not been explored in the research. The relationship among strategic decision-making logics, entrepreneurial capability and opportunity exploitation is moderated by a variety of internal organizational factors and external environmental factors. In future research, scholars can provide deeper insights into under what conditions strategic decision-making logics contribute more to opportunity exploitation and entrepreneurial capability in high-tech new ventures.

\section{Funding}

This work was supported by the National Natural Science Foundation of China (NSFC) under Grant [number 71602068, number 71620107001] and China Postdoctoral Science Foundation under Grant [number 2017T100215, number 2016M601388]. 


\section{Disclosure statement}

The author declares that she has no competing financial, professional, or personal interests from other parties.

\section{References}

Abdelgawad, S. G., Zahra, S. A., Svejenova, S., \& Sapienza, H. J. (2013). Strategic leadership and entrepreneurial capability for game change. Journal of Leadership \& Organizational Studies, 20(4), 394-407. https://doi.org/10.1177/1548051813475484

Ahlstrom, D., \& Bruton, G. D. (2010). Rapid institutional shifts and the co-evolution of entrepreneurial firms in transition economies. Entrepreneurship Theory and Practice, 34(3), 531-554. https://doi.org/10.1111/j.1540-6520.2010.00373.x

Alvarez, S. A., \& Barney, J. B. (2007). Discovery and creation: alternative theories of entrepreneurial action. Strategic Entrepreneurship Journal, 1(1-2), 11-26. https://doi.org/10.1002/sej.4

Ardichvili, A., Cardozo, R., \& Ray, S. (2003). A theory of entrepreneurial opportunity identification and development. Journal of Business Venturing, 18(1), 105-123. https://doi.org/10.1016/S0883-9026(01)00068-4

Aslan, I., Çınar, O., \& Kumpikaite, V. (2012). Creating strategies from tows matrix for strategic sustainable development of Kipaş Group. Journal of Business Economics \& Management, 13(1), 95-110. https://doi.org/10.3846/16111699.2011.620134

Baker, T., \& Nelson, R. E. (2005). Creating something from nothing: resource construction through entrepreneurial bricolage. Administrative Science Quarterly, 50(3), 329-366. https://doi.org/10.2189/asqu.2005.50.3.329

Baron, R. M., \& Kenny, D. A. (1986). The Moderator-mediator variable distinction in social psychological research: conceptual, strategic, and statistical considerations. Journal of Personality and Social Psychology, 51, 1173-1182. https://doi.org/10.1037/0022-3514.51.6.1173

Berends, H., Jelinek, M., Reymen, I., \& Stultiëns, R. (2014). Product innovation processes in small firms: combining entrepreneurial effectuation and managerial causation. Journal of Product Innovation Management, 31(3), 616-635. https://doi.org/10.1111/jpim.12117

Brettel, M., Mauer, R., Engelen, A., \& Küpper, D. (2012). Corporate effectuation: entrepreneurial action and its impact on R\&D project performance. Journal of Business Venturing, 27(2), 167-184. https://doi.org/10.1016/j.jbusvent.2011.01.001

Cai, L., Guo, R., Fei, Y., \& Liu, Z. (2017). Effectuation, exploratory learning and new venture performance: evidence from China. Journal of Small Business Management, 55(3), 388-403. https://doi.org/10.1111/jsbm.12247

Chandler, G. N., Detienne, D. R., Mckelvie, A., \& Mumford, T. V. (2011). Causation and effectuation processes: a validation study. Journal of Business Venturing, 26(3), 375-390. https://doi.org/10.1016/j.jbusvent.2009.10.006

Deligianni, I., Voudouris, I., \& Lioukas, S. (2015). Do effectuation processes shape the relationship between product diversification and performance in new ventures?. Entrepreneurship Theory and Practice, 2004(5), 891-893. https://doi.org/10.1111/etap.12210

Dew, N., Sarasathy, S., Read, S., \& Wiltbank, R. (2010). Affordable loss: behavioral economic aspects of the plunge decision. Strategic Entrepreneurship Journal, 3(2), 105-126. https://doi.org/10.1002/sej.66

Dutta, D. K., Gwebu, K. L., \& Wang, J. (2015). Personal innovativeness in technology, related knowledge and experience, and entrepreneurial intentions in emerging technology industries: a process of 
causation or effectuation?. International Entrepreneurship \& Management Journal, 11(3), 529-555. https://doi.org/10.1007/s11365-013-0287-y

Fisher, G. (2012). Effectuation, causation, and bricolage: a behavioral comparison of emerging theories in entrepreneurship research. Entrepreneurship Theory \& Practice, 36(5), 1019-1051. https://doi.org/10.1111/j.1540-6520.2012.00537.x

Foss, N. J., Lyngsie, J., \& Zahra, S. A. (2013). The role of external knowledge sources and organizational design in the process of opportunity exploitation. Strategic Management Journal, 34(12), 1453-1471. https://doi.org/10.1002/smj.2135

Guo, R., Cai, L., \& Zhang, W. (2016). Effectuation and causation in new internet venture growth: the mediating effect of resource bundling strategy. Internet Research, 26(2), 460-483.

https://doi.org/10.1108/IntR-01-2015-0003

Hmieleski, K. M., Carr, J. C., \& Baron, R. A. (2015). Integrating discovery and creation perspectives of entrepreneurial action: The relative roles of founding CEO human capital, social capital, and psychological capital in contexts of risk versus uncertainty. Strategic Entrepreneurship Journal, 9(4), 289-4312. https://doi.org/10.1002/sej.1208

Huarng, K. H., \& Ribeiro-Soriano, D. E. (2014). Developmental management: theories, methods, and applications in entrepreneurship, innovation, and sensemaking. Journal of Business Research, 67(5), 657-662. https://doi.org/10.1016/j.jbusres.2013.11.023

Maine, E., Soh, P. H., \& Santos, N. D. (2015). The role of entrepreneurial decision-making in opportunity creation and recognition. Technovation, 39(40), 53-72. https://doi.org/10.1016/j.technovation.2014.02.007

Markin, E., Swab, R., G., \& Marshall, D. R. (2016). Who is driving the bus? An analysis of author and institution contributions to entrepreneurship research. Journal of Innovation \& Knowledge, 2(1), 1-9. https://doi.org/10.1016/j.jik.2016.10.001

Mckelvie, A., \& Davidsson, P. (2009). From resource base to dynamic capabilities: an investigation of new firms. British Journal of Management, 20(1), 63-80. https://doi.org/10.1111/j.1467-8551.2008.00613.x

Milanov, H., \& Fernhaber, S. A. (2009). The impact of early imprinting on the evolution of new venture networks. Journal of Business Venturing, 24(1), 46-61. https://doi.org/10.1016/j.jbusvent.2007.11.001

Olugbola, S. A. (2017). Exploring entrepreneurial readiness of youth and start-up success components: Entrepreneurship training as a moderator. Journal of Innovation \& Knowledge, 2(3), 155-171. https://doi.org/10.1016/j.jik.2016.12.004

O’Reilly, C. A., \& Tushman, M. L. (2013). Organizational ambidexterity: past, present, and future. Academy of Management Perspectives, 27(4), 324-338. https://doi.org/10.5465/amp.2013.0025

Parida, V., George, N. M., Lahti, T., \& Wincent, J. (2016). Influence of subjective interpretation, causation, and effectuation on initial venture sale. Journal of Business Research, 69(11), 4815-4819. https://doi.org/10.1016/j.jbusres.2016.04.036

Patel, P. C., \& Jayaram, J. (2014). The antecedents and consequences of product variety in new ventures: an empirical study. Journal of Operations Management, 32(1-2), 34-50. https://doi.org/10.1016/j.jom.2013.07.002

Perry, J. T., Chandler, G. N., \& Markova, G. (2012). Entrepreneurial effectuation: a review and suggestions for future research. Entrepreneurship Theory and Practice, 36(4), 837-861. https://doi.org/10.1111/j.1540-6520.2010.00435.x

Powell, W. W., \& Sandholtz, K. W. (2012). Amphibious entrepreneurs and the emergence of organizational forms. Strategic Entrepreneurship Journal 6(2), 94-115. https://doi.org/10.1002/sej.1129 
Read, S., Song, M., \& Smit, W. (2009). A meta-analytic review of effectuation and venture performance. Journal of Business Venturing, 24(6), 573-587.

https://doi.org/10.1016/j.jbusvent.2008.02.005

Reymen, I. M. M. J., Andries, P., Berends, H., Mauer, R., Stephan, U., \& Burg, E. (2016). Understanding dynamics of strategic decision making in venture creation: a process study of effectuation and causation. Strategic Entrepreneurship Journal, 9(4), 351-379. https://doi.org/10.1002/sej.1201

Sarasvathy, S. D. (2001). Causation and effectuation: toward a theoretical shift from economic inevitability to entrepreneurial contingency. Academy of Management Review, 26(2), 243-263. https://doi.org/10.5465/amr.2001.4378020

Sarasvathy, S. D., \& Dew, N. (2005). New market creation through transformation. Journal of Evolutionary Economics, 15(5), 533-565. https://doi.org/10.1007/s00191-005-0264-X

Sarasvathy, S., Kumar, K., York, J. G., \& Bhagavatula, S. (2014). An effectual approach to international entrepreneurship: overlaps, challenges, and provocative possibilities. Entrepreneurship Theory and Practice, 38(1), 71-93. https://doi.org/10.1111/etap.12088

Shane, S., \& Venkataraman, S. (2000). The promise of entrepreneurship as a field of research. Academy of Management Review, 25(1), 217-226. https://doi.org/10.5465/amr.2000.2791611

Smolka, K. M., Verheul, I., Burmeister-Lamp, K., \& Heugens, P. P. M. A. R. (2016). Get it together! Synergistic effects of causal and effectual decision-making logics on venture performance. Entrepreneurship Theory and Practice. https://doi.org/ 10.1111/etap.12266

Stinchcombe, A. L. (1965). Social structure and organizations. Advances in Strategic Management, 17(17), 229-259.

Su, Z., Li, J., Yang, Z., \& Li, Y. (2011). Exploratory learning and exploitative learning in different organizational structures. Asia Pacific Journal of Management, 28(4), 697-714. https://doi.org/10.1007/s10490-009-9177-9

Teece, D. J. (2012). Dynamic capabilities: Routines versus entrepreneurial action. Journal of Management Studies, 49(8), 1395-1401. https://doi.org/10.1111/j.1467-6486.2012.01080.x

Uygur, U. (2016). An analogy explanation for the evaluation of entrepreneurial opportunities. Journal of Small Business Management. https://doi.org/10.1111/jsbm.12321

Vera, D., \& Crossan, M. (2005). Improvisation and innovative performance in teams. Organization Science, 16(3), 203-224. https://doi.org/10.1287/orsc.1050.0126

Wiltbank, R., Dew, N., Read, S., \& Sarasvathy, S. D. (2006). What to do next? The case for non predictive strategy. Strategic Management Journal, 27(10), 981-998. https://doi.org/10.1002/smj.555

Yli-Renko, H., Autio, E., \& Sapienza, H. J. (2001). Social capital, knowledge acquisition, and knowledge exploitation in young technology-based firms. Strategic Management Journal, 22(6-7), 587-613. https://doi.org/10.1002/smj.183

Zahra, S. A. (2012). Organizational learning and entrepreneurship in family firms: exploring the moderating effect of ownership and cohesion. Small Business Economics, 38(1), 51-65. https://doi.org/10.1007/s11187-010-9266-7

Zahra, S. A., Abdelgawad, S. G., \& Tang, E. W. K. (2011). Emerging multinationals venturing into developed economies. Journal of Management Inquiry, 20(20), 323-330.

https://doi.org/10.1177/1056492611408266 